\title{
Reducing primary dysmenorrhea among adolescent girls with mung bean extract drinks and stretching
}

\author{
Baiq Dewi Sukma Septiani ${ }^{1}$, Adi Prayitno ${ }^{2}$, Sugiarto ${ }^{3}$ \\ ${ }^{1}$ Master Program of Nutrition Science, Universitas Sebelas Maret, Indonesia \\ ${ }^{2}$ Department of Dental and Oral Disease, Postgraduate Program, Universitas Sebelas Maret, Indonesia \\ ${ }^{3}$ Department of Nutrition Science, Postgraduate Program, Universitas Sebelas Maret, Indonesia
}

\begin{tabular}{l} 
Article Info \\
\hline Article history: \\
Received Oct 01, 2018 \\
Revised Dec 10, 2018 \\
Accepted Jan 15, 2019 \\
\hline Keywords: \\
Adolescent girls \\
Mung bean extract drinks \\
Stretching \\
Primary dysmenorrhea \\
Stress
\end{tabular}

Article Info

Article history:

Received Oct 01, 2018

Revised Dec 10, 2018

Keywords:

Adolescent girls

Stretching

Stress

\begin{abstract}
Primary dysmenorrhea is pain during menstruation period due to high levels of prostaglandins F2 $\alpha$ in epithelial cells. Mung bean extract drinks contain several nutrients such as vitamin $\mathrm{C}$, calcium, carbohydrates and flavonoids as anti-depressants and anti-inflammatory agent. Stretching is a relaxation technique that could relieve menstrual pain in the abdominal part by increasing the production of endorphins functioning as neurotransmitters. To determine the effect of mung bean extract drinks and Stretching on primary dysmenorrhea in adolescent girls stressed. An open-label non-randomized controlled trial was used to 87 adolescent girls who experienced primary dysmenorrhea with moderate and severe stress levels from two boarding schools in Mataram, West Nusa Tenggara. They were divided into 3 groups, one group as the control and two groups as the experiment. The experiment of 29 students with pre and post-test. Mung bean extract drinks were given $250 \mathrm{ml} /$ day, stretching was given seven times/weeks before menstruation. Control and experimental group were observed for one month. Measurement of menstrual pain scale using the Numeric Rating Scale (NRS). Data analysis was used T-test. The mean menstrual pain for mung bean extract drinks with moderate stress levels was $1.31 \pm 1.32$ and significance at $p=0.004$, severe stress levels was $1.69 \pm 1.54$ and significance at $p=0.001$. The mean menstrual pain in for stretching experience moderate stress levels was $2.50 \pm 1.93$ and significance at $p=0.008$ while the severe stress level was $2.05 \pm 1.80$ and significance at $p=0.001$. The multivariate test multiple linear regression revealed that mung bean extract drinks and stretching contributed (-)0.106 $\mathrm{X}_{1}+(-) 0.116 \mathrm{X}_{2}+1.709$ $(p \leq 0.005)$. Mung bean extract drinks and stretching affected the reduction of primary dysmenorrhea in adolescent girls both at moderate and severe stress levels.
\end{abstract}

Copyright (c) 2019 Institute of Advanced Engineering and Science. All rights reserved.

\section{Corresponding Author:}

Baiq Dewi Sukma Septiani,

Master Program of Nutrition Science, Postgraduate School,

Universitas Sebelas Maret, Surakarta, Indonesia.

Email: dewisukma180989@gmail.com

\section{INTRODUCTION}

Mung bean extract drinks is a de-verified mung bean processed foods with some nutrients that are beneficial for dysmenorrhea, including vitamin $\mathrm{C}$ that can affect tension contractility and relax uterine smooth muscle, thereby reducing stress and inhibition of prostaglandin biosynthesis [1]. Calcium and carbohydrates in mung bean that can carry anti-depressant substances in the body during menstruation and can support reproductive hormones [2]. The content of flavonoids in mung beans is useful as an anti-inflammatory which can reduce prostaglandin levels so as to reduce menstrual pain [3]. The content of flavonoids in mung bean extract drinks, mung bean sprouts and fermented mung bean as much as $200 \mathrm{mg} / \mathrm{kg}$ 
and $1000 \mathrm{mg} / \mathrm{kg}$ is useful as an anti-inflammatory by inhibiting inflammatory mediators namely nitric oxide (NO) and inhibiting pain [4].

Stretching is a relaxation technique that can helps to relieve menstrual pain in the abdominal part through increased production of endorphins [5]. Endorphins are endogenous peptide opioids that function as neurotransmitters. Endorphins have the same structure as morphine, a drug used for pain relief [6]. Stretching is not permitted during menstruation. The results of this study are stretching is effective in reducing the intensity and duration of pain in adolescents with primary dysmenorrhea [7]. Research on female students in Iran who are not athletes regarding the effects of physical activity on primary dysmenorrhea results that there is a significant reduction in pain after physical activity [8]

Adolescence is a transition period from children to adults [9]. Indonesia has a population of 10-19 year olds reaching 43 million people or $18 \%$ of the 269 million Indonesian population [10]. Indonesian Health Profile Data 2017, the number of girls aged 15-19 years is 10,847,326 million [11]. Statistical Central Biro of West Nusa Tenggara in 2016 states that the number of girls aged 15-19 years is 218,014 people [12]. At this time there is a dynamic development phase in the life of an individual including puberty that is sexual maturity which is marked by the presence of menarche (first menstruation) [9]. Data from the Indonesian Demographic and Health Survey in 2012 stated that $95 \%$ of girls experienced menarche aged 12-15 years [13]. Menarche in first menstruation is one sign of a reproductive period in girls [14]. Furthermore, this menstrual process takes place regularly every month starting about 14 days after ovulation. But many of them in this menstrual period experience problems, especially in adolescence often experience menstrual pain (dysmenorrhea) [15].

Dysmenorrhea comes from the Greek language, dysmenorrheal, which according to the meaning of the word consists of "dys" means that it is difficult "meno" means the moon and "rrhea" means the flow so that dysmenorrhea is abdominal pain originating from uterine cramps and occurs during menstruation [16]. Pain in primary dysmenorrhea and other systemic symptoms is caused by high levels of prostaglandins, especially prostaglandin F2 $\alpha$ (PGF2 $\alpha$ ) in epithelial cells. Prostaglandin F $2 \alpha$ causes myometrium hyper-tonus and vasoconstriction to cause the uterine muscles to contract resulting in narrowing of the endometrial blood vessels, tissue ischemia, bleeding and pain [17]. The incidence of dysmenorrhea in Indonesia was $64.25 \%$ which consisted of $54.89 \%$ primary dysmenorrhea and $9.36 \%$ secondary dysmenorrhea [18]. Primary dysmenorrhea usually occurs in the second or third year after menarche, when ovulation starts regularly. Pain can be accompanied by nausea, vomiting, diarrhea, headache, lower back pain, irritability, fatigue and so on. Pain begins to be felt in the first 24hours of menstruation and can last for 48-72 hours. [19]. Dysmenorrhea causes intolerance in activity, which results in absence of work or school. This causes a decrease in work output and concentration in class. Women who experience dysmenorrhea become moody, irritable, unable to interact effectively with others and have trouble sleeping and restlessness [20]. Thus to reduce the intensity of menstrual pain (dysmenorrhea) can be done with non-pharmacological therapy and reduce stress [21].

\section{RESEARCH METHOD}

This research is an experimental study of non-randomized controlled trial open-label with pre-post design research design that is by comparing changes in results in the experiment group and the control group.This study was conducted on female students with moderate and severe stress levels who experienced primary menstrual pain in March-April 2018 at 2 Islamic Boarding Schools in Mataram City, West Nusa Tenggara Province, Indonesia. There are 58 adolescent girls with each group of experiment and control as many as 29 adolescent girls. Sample selection techniques are based on inclusion and exclusion criteria. Inclusion criteria included adolescent girls in class X and XI aged 15-17 years who experienced primary menstrual pain with regular menstrual cycles every month, had normal nutritional status, settled in a boarding school environment and agreed to participate in this study. Exclusion criteria included adolescent girls who received analgesic and anti-pain medication therapy, adolescent girls who smoked, used contraceptive drugs and consumed alcohol as well as adolescent girls with less nutritional status, overweight and obesity.

Mung bean extract drinks experiment group were given $250 \mathrm{ml} /$ day mung bean extract drinks for 7 days before menstruation. The mung bean were extracted from 200 grams of mung beans and made into 250 $\mathrm{ml}$ of mung bean extract drinks. Stretching is given once a day for 7 days before menstruation with steps, namely: (1) the respondent is asked to stand behind a chair, leaning forward so that the shoulders and back are in a straight line and the upper body is parallel to the floor. The duration of the exercise is 5 seconds, repeated for 10 times, (2) the second step is the respondent is asked to stand $10-20 \mathrm{~cm}$ behind the chair, then lift one heel from the floor, with a duration of 5 seconds then repeated with the heel of the other. This exercise was carried out 20 times, (3) the third step was the respondents were asked to spread their legs shoulder width apart, put their hands forward in a stretched state, then fold their knees and hold the squatting

Reducing primary dysmenorrhea among adolescent girls with mung bean extract drinks and... (Baiq Dewi S) 
position. The duration of this exercise for 5 seconds was repeated 10 times. (4) The fourth step in the middle and head position turned towards the left hand. This exercise is repeated 10times for each part of the body for duration of five seconds. (5) The fifth step is the respondent is asked to lie flat on his back, then the knee is bent with the help of the hand until it touches the chin. This step is repeated 10 times with duration of five seconds. (6) The sixth step is the respondent is asked to stand leaning against the wall and put his hand behind the head and elbow facing straight in the direction of the eye. This exercise was carried out for 10 minutes then observed for 1 month.

Data collected including data on general characteristics of respondents such as age, menstrual history data (menarche), nutritional status (BMI/Age) with anthropometric measurements of body weight $(\mathrm{kg})$ and height $(\mathrm{cm})$, stress level data and primary menstrual pain scale data. Retrieval of respondent' general characteristics data and menstrual history data using Questionnaire Sheets, stress level data retrieval using questionnaire Perceived Stress Scale 10 items (PSS-10). The questions in the PSS ask about feelings and thoughts during the last month. In each case, respondents are asked how often they felt a certain way. PSS is a Likert type scale where $0=$ Never, 1=Almost Never, 2=Sometimes, 3=Fairly Often, 4=Very Often. PSS scores are obtained by reversing responses (e.g., $0=4,1=3,2=2,3=1 \& 4=0$ ) and then summing across all scale items with a total score of 0-40. The subjects who scored 0-13 on the PSS where categorized to have mild stress levels, moderate stress levels if score 14-26, severe stress level if 27-40 [22-23]. Nutritional status (BMI/Age) is determined by Anthropometric data collection includes measuring body weight $(\mathrm{kg})$ using a digital scale with accuracy of $0.1 \mathrm{~kg}$, measuring height $(\mathrm{cm})$ using microtoise with accuracy of $0.1 \mathrm{~cm}$. Evaluation of menstrual pain scale is using the Numeric Rating Scale (NRS) scale of 0-10 [10].

Univariate analysis was used to determine the frequency distribution of the general characteristics of respondents and the scale of menstrual pain both before and after the intervention of mung bean extract drinks and stretching the subject of the study. Analysis of homogeneity and normality is used to determine the distribution of data and tests that will be used to analyze the effect of independent variables on the dependent variable. Bivariate analysis was used to explain the effect of mung bean extract drinks and stretching exercises on stressed adolescent girls with primary dysmenorrhea. The statistical test used was the T-test. If there is a significant difference, there is an influence of mung bean extract drinks and stretching exercise on menstrual pain in adolescent girls. Multivariate analysis was used to explain the effect of independent variables on the dependent variable by using Multiple linear regression statistical tests.

\section{RESULTS AND DISCUSSION}

In this section, it is explained the results of research and at the same time is given the comprehensive discussion. Results can be presented in figures, graphs, tables and others that make the reader understand easily [2-5]. The discussion can be made in several sub-chapters. Table 1 shows that mean of age, age first menarche, stress level and BMI/Age as nutritional status in the group of control, mung bean extract drinks and stretching. This study was conducted on 87 respondents at the age of 15-17 years with the mean age namely $15.90 \pm 0.61$ years, while the mean age first menarche was $12.98 \pm 0.93$ years, the mean stress level was $27.46 \pm 6.59$ point and the mean BMI/age is $-0.06 \pm 0.58$. Table 2 reveals that have homogenous and normal distribution of primary menstrual pain scale between control and before mung bean extract drinks and stretching experience with moderate and severe stress level was $p \geq 0.005$.

Table 3 shows the significant difference in first menarche scale between before and after experience of mung bean extract drinks with value of moderate stress level is $p=0.004$, while in severe stress is $p=0.001$. The significant difference in first menarche scale showed between before and after experience of stretching with value of moderate stress level is $p=0.008$, while severe stress was $p=0.001$. Table 4 describes the results that by Independent-test have a significant effect of mung bean extract drinks on the reduction of primary menstrual pain scale in adolescent girls with moderate stress levels $(p=0.004)$ and severe stress levels $(p=0.005)$.

Table 5 reveals the results that by Independent-test have a significant effect of stretching on the reduction of primary menstrual pain scale in adolescents girls with moderate stress levels $(p=0.002)$ and severe stress levels $(p=0.007)$. Table 6 presents the results of multivariate analysis between mung bean extract drinks and stretching experience using multiple linear regression analysis shows that mung bean extract drinks and stretching experience significantly affected to reduce the primary menstrual pain scale by line $\mathrm{y}=(-) 0.106 \mathrm{X}_{1}+(-) 0.116 \mathrm{X}_{2}+1.709(\mathrm{p} \leq 0.005)$ and contributed $41.3 \%$ to reduce the primary menstrual pain scale in adolescent girls with stress. Mung bean extract drinks and stretching experience with confounding factors significantly affected to reduce the primary menstrual pain scale by line $\mathrm{y}=(-) 0.015 \mathrm{X}_{1}+(-) 0.028 \mathrm{X}_{2}+2.000(\mathrm{p} \leq 0.005)$ and contributed $82.9 \%$ to reduce the primary menstrual pain scale in adolescent girls with stress. 
Table 1. General characteristics of respondents

\begin{tabular}{ccccc}
\hline $\begin{array}{c}\text { General } \\
\text { Characteristics }\end{array}$ & $\begin{array}{c}\text { Total } \\
(n=87)\end{array}$ & $\begin{array}{c}\text { Mung Bean Extract } \\
\text { Drink }(n=29)\end{array}$ & $\begin{array}{c}\text { Stretching } \\
(n=29)\end{array}$ & $\begin{array}{c}\text { Control } \\
(n=29)\end{array}$ \\
\hline Age (years) & $15.90 \pm 0.61$ & $15.72 \pm 0.59$ & $15.76 \pm 0.58$ & $16.21 \pm 0.56$ \\
Age (first Menarche) & $12.98 \pm 0.93$ & $12.66 \pm 0.97$ & $13.00 \pm 0.96$ & $13.28 \pm 0.75$ \\
Stress level & $27.46 \pm 6.59$ & $27.62 \pm 6.11$ & $29.93 \pm 5.35$ & $24.83 \pm 7.35$ \\
BMI/Age & $-0.06 \pm 0.58$ & $0.08 \pm 0.60$ & $-0.19 \pm 0.52$ & $-0.08 \pm 0.61$ \\
\hline
\end{tabular}

Table 2. Test the normality and homogeneity of the research variables

\begin{tabular}{cccc}
\hline & Independent Variable & $\begin{array}{c}\text { Homogeneity } \\
\text { p-value }\end{array}$ & $\begin{array}{c}\text { Normality } \\
\text { p-value }\end{array}$ \\
\hline Control & $\begin{array}{c}\text { Moderate stress (before and after) } \\
\text { Severe stress (before and after) }\end{array}$ & 0.565 & 0.065 \\
Mung Bean & Control and before mung bean extract & 0.851 & 0.151 \\
$\begin{array}{c}\text { Extract } \\
\text { Stretching }\end{array}$ & control and before stretching experiance & 0.933 & 0.200 \\
\hline
\end{tabular}

Table 3. Mean of before and after for primary menstrual pain of mung bean extract drinks experience

\begin{tabular}{ccccccc}
\hline $\begin{array}{c}\text { Independent } \\
\text { Variable }\end{array}$ & Stress Level & $n$ & \multicolumn{2}{c}{ Primary Menstrual Pain Scale } & Paired-Test \\
before & after & Delta & (p-value) \\
\hline Mung Bean & Moderate stress & 13 & $4.23 \pm 2.71$ & $2.92 \pm 1.60$ & $1.31 \pm 1.32$ & 0.004 \\
Drinks & Severe stress & 16 & $4.06 \pm 2.64$ & $2.38 \pm 2.42$ & $1.69 \pm 1.54$ & 0.001 \\
Stretching & Moderate stress & 8 & $3.88 \pm 1.89$ & $1.38 \pm 0.92$ & $2.50 \pm 1.93$ & 0.008 \\
& Severe stress & 21 & $3.24 \pm 2.36$ & $1.19 \pm 1.50$ & $2.05 \pm 1.80$ & 0.001 \\
\hline Significance $p=0.05$ level (2-tailed) & & & & &
\end{tabular}

Table 4. Mean of difference between control and experience with mung bean extract drinks on primary menstrual pain

\begin{tabular}{|c|c|c|c|c|c|}
\hline \multirow{2}{*}{\multicolumn{2}{|c|}{ Perceived Stress Score }} & \multirow[b]{2}{*}{$\mathrm{n}$} & \multicolumn{2}{|c|}{ Primary Menstrual Pain Scale } & \multirow{2}{*}{ T-test } \\
\hline & & & Mung Bean Extract Drinks & Control & \\
\hline Moderate Stress & $14-26$ & 30 & $1.31 \pm 1.32$ & $-0.18 \pm 1.24$ & 0.004 \\
\hline Severe Stress & $27-40$ & 28 & $1.69 \pm 1.54$ & $-0.08 \pm 1.50$ & 0.005 \\
\hline
\end{tabular}

Table 5. Mean of Difference between control and experience with stretching on primary menstrual pain

\begin{tabular}{lccccc}
\hline \multirow{2}{*}{ Perceived Stress Score } & $n$ & \multicolumn{2}{c}{ Primary Menstrual Pain Scale } & \multirow{2}{*}{ T-test } \\
\hline Moderate Stress & $14-26$ & 25 & $2.50 \pm 1.93$ & $-0.18 \pm 1.24$ & $p=0.002$ \\
Severe Stress & $27-40$ & 33 & $2.05 \pm 1.80$ & $-0.08 \pm 0.43$ & $p=0.007$ \\
\hline *Significance $p=0.05$ level (2-tailed)
\end{tabular}

*Significance $p=0.05$ level (2-tailed)

Table 6. Regresi linear for mung bean extract drinks

\begin{tabular}{|c|c|c|c|c|c|c|}
\hline \multirow{2}{*}{ Model } & \multicolumn{2}{|c|}{ Unstandardized Coefficients } & \multirow{2}{*}{$\begin{array}{c}\text { Standardized Coefficients } \\
\text { Beta }\end{array}$} & \multirow{2}{*}{$\mathrm{t}$} & \multirow{2}{*}{$\begin{array}{c}\mathrm{p}- \\
\text { value }\end{array}$} & \multirow{2}{*}{$\begin{array}{c}\mathrm{R} \\
\text { Square }\end{array}$} \\
\hline & B & Std. Error & & & & \\
\hline \multicolumn{7}{|l|}{ Model $_{1}$} \\
\hline Constant & 1.709 & 0.042 & - & 27.521 & 0.001 & \multirow{3}{*}{0.413} \\
\hline Mung Bean Extract Drinks & -0.106 & 0.030 & -0.296 & -2.534 & 0.014 & \\
\hline Stretching & -0.116 & 0.062 & -0.449 & -3.848 & 0.001 & \\
\hline \multicolumn{7}{|l|}{ Model $_{2}$} \\
\hline Constant & 2.000 & 0.630 & - & 3.177 & 0.003 & \\
\hline Mung Bean Extract Drinks & -0.015 & 0.029 & -0.043 & -0.530 & 0.001 & \\
\hline Stretching & -0.028 & 0.021 & -0.107 & -1.334 & 0.001 & 0829 \\
\hline \multicolumn{7}{|l|}{ Age (years) } \\
\hline Age (first Menarche) & 0.038 & 0.038 & 0.069 & 0.997 & 0.324 & \\
\hline Stress Level & -0.003 & 0.005 & -0.039 & -0.564 & 0.575 & \\
\hline BMI/Age & -0.046 & 0.054 & -0.055 & -0.839 & 0.406 & \\
\hline
\end{tabular}

*Significance $p=0.05$ level (2-tailed) 


\section{DISCUSSION}

This study aims to analyze the effect of mung bean drinks and stretching on the reduction of the primary menstrual pain scale of girls aged 15-17 years with moderate and severe stress levels. The mung bean drinks and stretching were given to 29 adolescent girls for 7 days before menstruation while 29 other adolescent girls were without experiment (research control). Based on the results of the study, it is known that adolescent girls with moderate stress levels after being given mung bean extract drinks for seven days experienced have decrease in menstrual pain scale $(p=0.004)$ as well as severe stress levels $(p=0.001)$. The other hand, stretching has a significant effect on decreasing the primary menstrual pain scale of adolescent girls both at moderate stress levels $(p=0.002)$ and severe stress levels $(p=0.007)$. There is a correlation between dysmenorrhea and stress levels [24]. Stress causes a neuroendocrine response that causes Corticotropic Releasing Hormone $(\mathrm{CRH})$ which is the main hypothalamic regulator stimulating adrenocorticotrophic hormone (ACTH) secretion. Adrenocorticotrophic hormone stimulates the adrenal glands to produce cortisol which is a steroid hormone that stimulates the release of fat, sugar and amino acids into the blood to produce energy [25]. Increased cortisol secretion is associated with decreased levels of dehydroepiandrosterone (DHEA) which has an anabolic effect as opposed to cortisol, causing disruption of the secretion of sex hormones which results in decreased levels of progesterone. Progesterone affects the synthesis of prostaglandins PGF2a and PGE2 and the binding of prostaglandins to the myometrial receptors. Prostaglandins affect the uterine muscles and vascular tone [26]. High levels of prostaglandin F2 $\alpha$ (PGF2 $\alpha$ ) in epithelial cells also affect pain during menstruation due to myometrial hypertonus and vasoconstriction causing the uterine muscles to contract resulting in narrowing of the endometrial blood vessels, tissue ischemia, bleeding and pain [9].

Some nutrient content in mung bean drinks have a positive effect on decreasing menstrual pain scale including flavonoid content can inhibit prostaglandin biosynthesis (PGE2) by suppressing the activity of COX-2 enzyme through inhibition of NF-KB gene expression. Antioxidant activity in flavonoids is also able to inhibit reactive oxygen species (ROS), especially those involved in pathological inflammation [14, 27]. Increased intake of simple carbohydrates during the luteal phase is associated with increased mood during the menstrual period because carbohydrates increase the availability of tryptophan as a serotonin precursor in the brain [15]. The presence of vitamin $\mathrm{C}$ in mung bean is useful as an anti-depressant through the conversion of dopamine to norepinephrine and as a cofactor of tryptophan-5-hydroxilase to convert tryptophan to 5-hydroxytryptophan in serotonin production to make nerve function return to normal, this can reduce stress levels [28] In addition, vitamin C can also affect tension contractility and relax the uterine smooth muscle thus reducing stress and inhibiting prostaglandin biosynthesis [14]. Calcium plays a role in the interaction of proteins in the muscles, namely actin and myosin, resulting in contractions. After less than a second, calcium is pumped back into the sarcoplasmic reticulum where ions are stored until the new action potential of the muscle returns. Expulsion of calcium ions from myofibril will cause muscle contractions to stop [29].

Stretching has a positive effect on dysmenorrhea by increasing circulatory metabolism of pelvic blood flow and activating endorphins so as to prevent an increase in prostaglandin levels to reduce ischemic pain during menstruation [30]. Stretching or exercise can be done for 30 minutes every day and can be done 7 days before menstruation. During exercise, endorphin production increases and will be released and captured by receptors in the hypothalamus and limbic system. The endorphins will function in emotional settings resulting in a decrease in pain [31]. Endorphins are produced in the body by the pituitary gland. Endorphins inhibit the release of gamma amino-butyric acid (GABA). This inhibition will cause an increase in dopamine production associated with pleasure. The endorphins produced when exercising are then channeled throughout the body and act as natural analgesics in the body [32].

\section{CONCLUSION}

The research suggested that giving the mung bean extract drinks $250 \mathrm{ml} /$ day for 7 days before menstruation has a significant effect on reducing the primary dysmenorrhea among adolescent girls both at moderate and severe stress levels. Stretching was given once a day for 7 days before menstruation affected on reducing the primary dysmenorrhea among adolescent girls both at moderate and severe stress levels. Mung bean extract drinks and stretching can be used as a non-pharmacological therapy for reducing menstrual pain in adolescent girls. Further research is needed in regard to the timing of giving the right mung bean extract drinks and stretching to help reduce primary dysmenorrhea among adolescent girls.

\section{REFERENCES}

[1] Ekawati H. Effect of Giving Papaya Leaves (Carica Papaya Linn) on Decreasing Menstrual Pain (Dysmenorrhea) in Young Women in Early Tarbiyatul Ulum Madrasa Wustho Pilang Laren Lamongan. Surya (in Bahasa: Pengaruh 
Pemberian Daun Pepaya (Carica Papaya Linn) terhadap Penurunan Nyeri Haid (Dismenore) pada Remaja Putri di Madrasah Diniah Tarbiyatul Ulum Wustho Pilang Laren Lamongan. Surya), 2015, 7(2). pp. 47-53.

[2] Barbosa, D.E.C. Rosse De Souza V. Santos, L.A.S. Chiappini, C.C. Sa, A.S. Azeredo, V.B. Changes in Taste and Food Intake during the Menstrual Cycle, Journal of Nutrition \& Food Sciences, 2015, 5(4). pp. 1-6.

[3] Guo X. Li T. Tang K. Liu RH. Effect of Germination on Phytochemical Profiles and Antioxidant Activity of Mung Bean Sprouts ( Vigna radiata ), J. Agric. Food Chem., 2012, 60(44). pp.11050-11055.

[4] Ali, NM. Mohd Yusof H. Yeap, SK. Ho, WY. Beh, BK. Long, K. Koh, SP. Abdullah, MP. Alitheen, NB. AntiInflammatory and Antinociceptive Activities of Untreated, Germinated, and Fermented Mung Bean Aqueous Extract, Evidence-Based Complementary and Alternative Medicine, 2014, pp.1-6. http://dx.doi.org/10.1155/2014/350507.

[5] Salbiah, Decreased Pain Levels During Menstruation Through Abdominal Streching Exercises, Journal of Nursing (in Bahasa: Penurunan Tingkat Nyeri Saat Menstruasi Melalui Latihan Abdominal Streching, Jurnal Ilmu Keperawatan. 2017, 1(1). pp.72-82.

[6] Rokade, P.B. Release of Endomorphin Hormone and Its Effects on Our Body and Moods: A Review. International Conference on Chemical, Biological and Environment Sciences (ICCEBS'2011) Bangkok, 2011, pp.436-438

[7] Shahr-jerdy, S. Hosseini R.S. Gh, M.E. Effects of Stretching Exercises on Primary Dysmenorrhea in Adolescent Girls, Biomedical Human Kinetics, 2012, 4(1). pp.127-132.

[8] Mahvash, N. Eidy, A. Mehdi, K. Zahra, M.T. Mani, M. Shahla, H.The Effect of Physical Activity on Primary Dysmenorrhea of Female University Students, World Applied Sciences Journal, 2012,17(10).pp.1246-1252.

[9] Soetjiningsih.Tumbuh Kembang Anak, 2013, EGC, Jakarta, 2013

[10] Cappa, C. Wardlaw, T. Langevin-Falcon, C. Diers J. Progress for Children A Report Card on Adolescents, The Lancet, 2012. 379(9834). pp.2323-2325

[11] No Name. Indonesian Health Profile (in Bahasa: Profil Kesehatan Indonesia 2017. Ministry of Health Republic of Indonesia), 2018. http://www.depkes.go.id/. Accessed 15 agustus 2018.

[12] No Name. Population by Regency / City and Gender in West Nusa Tenggara Province 2016 West Nusa Tenggara Statistics Agency (in Bahasa: Jumlah Penduduk Menurut Kabupaten/Kota dan Jenis Kelamin di Provinsi Nusa Tenggara Barat 2016. Badan Pusat Statistik Nusa Tenggara Barat. 2016.Accessed 08 Februari 2018.https://ntb.bps.go.id/

[13] National Population and Family Planning Board. Ministry of Health, Indonesia Demographic and Health Survey 2012 : Adolescent Reproductive Health. Statistics, 2013, Statistics Indonesia, pp.79-87, Accessed 15 Agustus 2018 http://microdata.worldbank.org/index.php/catalog/2911/

[14] Gumanga, S K; Kwame-Aryee, R A.Menstrual Characteristics in Some Adolescent Girls in Accra Ghana, Ghana Medical Journal, 2012, 46(1). pp.3-7.

[15] Savitri,R. Gambaran Skala Nyeri Haid pada Usia Remaja. Jurnal Keperawatan Aisyiyah, 2015, 2(2). pp.25-29.

[16] Chauhan M, Kala, J. Relation between Dysmenorrhea and Body Mass Index in Adolescents with Rural Versus Urban Variation. J Obstet Gynecol India. 2012. 62(4). pp.442-445.

[17] Sultan C. Gaspari L. Paris F. Adolescent Dysmenorrhea. Pediatric and Adolescent Gynecology Evidence-Based Clinical Practice. 2012. 22(10). pp.171-180.

[18] Fahimah. Margawati, A.Fitranti, D.Y. Relationship between Omega-3 Fatty Acid Consumption, Physical and Percent Activity of Body Fat with Levels of Dysmenorrhea in Adolescents (in Bahasa: Hubungan Konsumsi Asam Lemak Omega-3, Aktivitas Fisik dan Persen Lemak Tubuh dengan Tingkat Dysmenorrhea pada Remaja). Journal of Nutrition College. 2017. 6(4). pp.268-276.

[19] Vaziri F. Hoseini A. Kamali F. Abdali K. Hadianfard M. Sayadi M. Comparing the Effects of Aerobic and Stretching Exercises on the Intensity of Primary Dysmenorrhea in the Students of Universities of Bushehr. Journal of Family and Reproductive Health. 2015. 9(1). pp. 23-28.

[20] Zannoni L. Giorgi M. Spagnolo E. Montanari G. Villa G. Seracchioli R.Dysmenorrhea, Absenteeism from School, and Symptoms Suspicious for Endometriosis in Adolescents.J Pediatr Adolesc Gynecol. 2014. 27(5). pp.258-265.

[21] Homai HM. Shafai FS. Zoodfekr L. Comparing Menarche Age, Menstrual Regularity, Dysmenorrhea and Analgesic Consumption among Athletic and Non-Athletic Female Students at Universities of Tabriz-Iran. International Journal of Women's Health Reproduction Sciences, 2014. 2(5). pp.307-310.

[22] Cohen S, Kamarck T, Mermelstein R. A Global Measure ofPerceived Stress Scale. Journal of Health and Social Behavior. 1983. 24(4) pp.385-396. Accessed 08 Februari 2018. http://www.mindgarden.com/products/pss.htm

[23] Nagma S. Kapoor G. Bharti R. Batra A. Batra A. Aggarwal A. Sablok A. To Evaluate The Effect of Perceived Stress on Menstrual Function. Journal of Clinical and Diagnostic Research. 2015. 9(3). pp.QC01-QC03.

[24] Shirvani MA. Motahari-Tabari N. Alipour A. Use of Ginger Versus Stretching Exercises for The Experiment Of Primary Dysmenorrhea: a randomized controlled trial. J Integr Med. 2017. 15(4). pp.295-301

[25] Wang L. Wang X.WangW.Chen C. Ronnennberg A.G.Guang W. Huang A. Fang Z. ZangT.Wang L. Xu X. Stress and dysmenorrhoea: a population based prospective study. Occup Environ Med. 2004. 61(12). pp.1021-1026.

[26] Ekpenyong CE. Davis KJ. Akpan, U.P. Daniel, N.E. Academic Stress and Menstrual Disorders among Female Undergraduates in Uyo, South Eastern Nigeria - The need for health education.Niger J Physiol Sci. 2011. 26(2). pp.193-198.

[27] Mothana RAA. Al-Said MS. Al-Rehaily AJ. Thabet TM. Awad NA. Lalk M. Lindequist U. Anti-inflammatory, antinociceptive, antipyretic and antioxidant activities and phenolic constituents from Loranthus regularis Steud. ex Sprague. Food Chemistry. 2012.130(2). pp.344-349.

[28] Afriani Y. Hadjam NR. Farmawati A. Giving a combination drink of maltodextrin and vitamin C to the negative mood and VO2 max soccer athletes. Indonesian Clinical Nutrition Journal (in Bahasa: Pemberian minuman

Reducing primary dysmenorrhea among adolescent girls with mung bean extract drinks and... (Baiq Dewi S) 
kombinasi maltodekstrin dan vitamin C terhadap mood negatif dan VO2 maks atlet sepak bola.. Jurnal Gizi Klinik Indonesia). 2017. 13(4). pp.196-204.

[29] Safitri.; R. Rahman N. Hasanah. Relationship between Calcium Intake and Sports Activities with Dysmenorrhea in Class XI students in Palu State High School (in Bahasa: Hubungan Asupan Kalsium dan Aktivitas Olahraga dengan Kejadian Dismenore pada Siswi kelas XI di SMA Negeri2 Palu). Tadulako Health Journal (Jurnal Kesehatan Tadulako). 2015. 1(1). pp.58-69.

[30] Sutar A. Paldhikar S. Shikalgar N. Ghodey S. Effect of aerobic exercises on primary dysmenorrhoea in college student. IOSR Journal of Nursing and Health Science (IOSR-JNHS). 2016. 5(5). pp.20-24.

[31] Setyorini,Y. and Satino. Effectiveness of gymnastics with modules in reducing dysmenorrhoea in high school adolescents in the city of Surakarta (in Bahasa: Efektifitas senam dengan modul dalam mengurangi dismenorea pada remaja SMA di kota Surakarta). Integrated Health Sciences Journal (Jurnal Terpadu Ilmu Kesehatan).2016.5(2).pp.110-237.

[32] Sprouse-Blum AS. Smith G. Sugai D. Parsa FD. Understanding endorphins and their importance in pain management. Hawai'I Med J. 2010. 69(3). pp.70-71.

\section{BIOGRAPHIES OF AUTHORS}

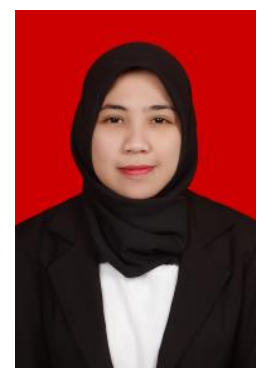

Baiq Dewi Sukma Septiani S.Gz was born on September 18, 1989. She got her bachelor degree from Universitas Respati Yogyakarta. Now she continue her study at Master Program of Nutrition Science Concentration on Clinical Nutrition, Postgraduate School, Universitas Sebelas Maret Surakarta from 2016 until now. She is a dietetic lecturer in S1 Nutrition Sciences at Universitas Nahdlatul Ulama NTB. Experience as an enumerator in Family Planning Advocacy Research to Improve Method of Contraception Variety in East Java Province and West Nusa Tenggara Province in 2016. Experience in Participating in Scientific Seminar Activities 12 times. Scientific writing seminar at the 13th Symposium on Nutri Indonesia in conjunction with 5th International Nutrition Symposium on Nutrition Innovation in Disease Prevention and Treatment and National Seminar II of Unversitas Sebelas Maret Surakarta. Research experience was 3 times with the title Relationship between Knowledge Level of Snack Food and School Food Choosing Practices of School Canteen at SMP 7 Mataram, Effect of Concentration of $\mathrm{NaCl}$ Solution on Physical Properties, Durability and Total Microbial Scattering of Tongkol Fish (Euthynnus affinis), The effect of Mung Bean Extract Drinks and Stretching Exercise for Primary Dysmenorrhea on Adolescent Girls.

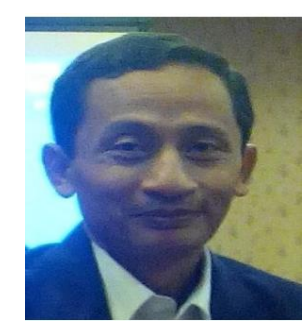

Dr. Adi Prayitno, drg., M.Kes was born on November 01 1959. His educational background was General Practitioner denstistry, Faculty of Dental Medicine Universitas Gadjah Mada (1985) . Postgraduate Program in Tropical Medicine, Universitas Gadjah Mada (1999) and completed his doctorate in Medical Faculty UNAIR Surabaya in the interest of Pathobiology in 2009. Now he currently serving as Head of Dental and Oral Disease Section at the Sebelas Maret University Medical Faculty (2007-now), Head of KSM Dental and Oral Disease, Dr. Moewardi Surakarta Hospital (2015-now), lecturer of infectious diseases, cancer and degeneration of the Postgraduate Program of PS-IKM Universitas Sebelas Maret (2014-now), lecturer Immunology Nutrition. Postgraduate program of Nutrition Science (2011-now), lecturer of S3 molecular biology at the Universitas Sebelas Maret Medical Faculty (2015-now). Journal scientific papers are 37 times and published in different international journals. Seminar scientific papers are 36 times. Acted as a reviewer in the Moewardi Medical Journal journal RSDM Surakarta (2013). Achievement as an exemplary lecturer in the field of community service in the Universitas Sebelas Maret Surakarta (2004). Second Place in the scientific writing competition (2003). The first winner in Listerine-FDI IDA Meeting (2015). A scientific Writing book entitled stressor, Hsp and Oral Cavity Cancer (2015) ISBN 978-602-8466-30-1

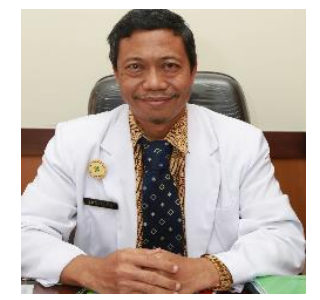

Dr.dr. Sugiarto, Sp.PD,KEMD,FINASIM was born on May 22, 1962. His educational background was General Practitioner, Faculty of Medicine, Universitas Sebelas Maret (19811988). Internal Medicine Specialist, Faculty of Medicine, Universitas Gadjah Mada (1988-2003), Postgraduate Program in Medical Sciences, Universitas Airlangga (2006-2010) and Endocrinology and Metabolic Consultant, Faculty of Medicine Unversitas Gadjah Mada (20112014). He had worked at Puskesmas in Brebes, Central Java as doctor (1989-1998), Internal Medicine Specialist Education, Faculty of Medicine, Unversitas Gadjah Mada (1998-2003), Endocrinology-Metabolism Section of Internal Medicine Science Dr Moewardi Hospital/Faculty of Medicine, Unversitas Sebelas Maret (2003-2017) and Doctoral Program of Public Health, Postgraduate School, Unversitas Sebelas Maret as lecturer staff (2017-now) 